\title{
Daddy, Mammy and Daughter Matters and the Fulfillment of Feminine Self in John Maxwell. Coetzee's In the Heart of the Country (1999)
}

Babacar Diakhaté*

Laboratoire d'Études Africaines Et Postcoloniales, Université Cheikh Anta Diop, Dakar, Sénégal

DOI: $\underline{10.36348 / \mathrm{sjhss} .2021 . \mathrm{v} 06 \mathrm{i} 01.003}$

| Received: 16.01.2021 | Accepted: 25.01.2021 | Published: 29.01.2021

*Corresponding author: Babacar Diakhaté

\section{Abstract}

This article shows John Maxwell Coetzee's shift from literary themes such as racism, discrimination and alienation to imaginative literature. The author tackles love, sex, parents-daughter issues, etc. In In the Heart of the Country (1999) [1], Coetzee presents Magda, an old South African woman who lives in her father's isolated farms and who wants to "love and be loved", to "need and be needed", to cover and be covered. This old spinster yarns to be a human being before being a woman. Magda's loneliness and madness are engendered by the death of her mother while she gives birth to an heir son to her husband. She also kills her father after having sexual intercourse with his female servant, Klein Anna.

Keywords: Femininity, Sexual Intercourse, Imagination, Daddy Issues, Madness.

Copyright (C) 2021 The Author(s): This is an open-access article distributed under the terms of the Creative Commons Attribution 4.0 International License (CC BY-NC 4.0) which permits unrestricted use, distribution, and reproduction in any medium for non-commercial use provided the original author and source are credited.

\section{INTRODUCTION}

Most of John Maxwell Coetzee's writings are related to racial segregation, master-slave relationships, alienation, etc. These aforementioned themes are recurrent in Disgrace (2013) [2] and Dusklands (1974, 1982) [3].In the Heart of the Country, Coetzee deals with imagination, love, sexuality, daddy issues, to name but a few. In the novel, the author introduces Magda, an intelligent, unattractive, spinster daughter of a European sheep farmer who is in quest for a man to fulfill her sexual desires. Magda is rejected, denied and betrayed by her father and abandoned by her dead mother who does not succeed to give an heir son to her husband.

The aim of this article is to display how the lack of sexual satisfaction can prevent an old spinster from being a woman. It also shows whether all means necessary are good for a frustrated and isolated woman to fulfill her sexual desires. The first part focuses on daddy, mummy and daughter issues. The second part lays emphasis on sexual relationships between, Magda, her father and their black servants. The last section reveals the final situation after Magda's search for femininity affirmation.

\section{The Absence of Mother and Father figures}

Living with one's parents symbolizes, love, guarantee and shelter for the child. It also shows the fertility and the future legacy of the parents. However, the absence of the son or parents constitutes a big "hole". In Everything Good Will Come (2004) [4], Sefi Atta depicts the absence of Enitan's father when she really needs him. The imprisonment of her father triggers off her courage and commitment to perpetuate the edition of his journal and contribute to his total liberation. As for Enitan's mother, she is physically present but she does not play her role towards her daughter. Sheri, Enitan's immature friend, teaches her what sexual intercourse means: Banana into tomato. Don't you know about it? [4].

In In the Heart of the Country, Coetzee underscores the gravity and danger of Mother/Father figure absence during the son's growth. In the novel, the author presents Magda, a young female Afrikaner who inherits and perpetuates the works of her father and ancestors in the farmhouse. She is presented as a severe character in the novel because of her father who is physically present but absent when his daughter needs him. Magda needs to be accepted and shown a happy face by her father. Gamal develops that Magda experiences a poor self-worth, and an inability to feel deserving worthy of receiving what she needs and wants [5].

Magda wishes her father's death as he (father) is responsible for her mother's. Magda is ignored and 
shown indifference by her father. She is abandoned by her mother who dies when she gives birth to a child. The death of Magda's mother is caused by her husband's oppression. Indeed, he asks his wife to give him a son to be the heir of the family. Coetzee writes:

Her husband never forgave her for failing to bear him a son. His relentless sexual demands let to her death in childbirth...the doctor came too late. Summoned by a messenger on a bicycle, he had to cart. When he arrived my mother already lay composed on her death bed, patient, bloodless, apologetic [1].

The death of her mother during the baby deliverance shows that some Africans develop a keen interest for an heir son. Kambarami reveals that in the African family male child is preferred to female child and is upheld as a "king" [6]. Magda's mother's death is a relief for her father. His wife is unable to give him an heir son in a patriarchal society in which man is considered to be "more productive" than woman. Magda rebels against her father:

To my father I have been an absence all my life. Therefore, instead of being the womanly warmth at the heart of this house I have been a zero, null, a vacuum towards which all collapses inward, a turbulence, muffled, grey, like a child draft eddying through the corridors, neglected vengeful [1].

As a result, the death of her mother and the indifference of her father illustrate Magda's solitude. She confesses:

(...) And the absence of my mother. My father is the absence of my mother her negative, her death. She the soft, the fair; he the hard, the dark. He has murdered all the motherly in me and left me this brittle hairy shell will peas of dead words rattling in it. I stand in the empty kitchen hating him [1].

Sefi Atta Shows that the less attachment of the mother to her daughter pushes the daughter to resort to other figures like a nanny, a grandmother or even an immature friend as shown between Enitan and Sheri. In In the Heart of the Country, Coetzee reveals that the absence of her father and the death of her mother are the incentive factors that drive Magda to have sexual intercourse with Hendrik. Magda asserts: “...mother who drugged me with milk and slumber in the featherbed and then, to the sound of bells in the night, vanished leaving me alone among rough hands and hard bodies-where are you?" [1].

The attachment of Magda to her father starts when he invites female visitors in the house to satisfy his sexual desires. His manhood and virility attract Magda to imagine being impregnated by her own father: I can imagine too falling pregnant after many moons, though it would not astonish me if I were barren, I look like a popular nation of the barren woman , and then, after seven or eight months, giving birth to a child (...) [1].
The father figure in Magda's existence is very complex. On the one hand, she hates her father for illtreating her mother to death. On the other hand, she is a fan of her father who invites Klein Anna to have sexual intercourse with her. Furthermore, Magda fetches water for her father to have a bath so that she can inhale the perfume of her father's soap. She owns up: "the heavy miasma of soap and sweat"...she inhales "male flesh, white, heavy, dumb, whose flesh can it be but his"? [1]. The smell of a male flesh when her father is having a bath engenders Magda's envy, love and jealousy. She realizes that her father has a servant mistress who plays the role that Magda's dead mother was supposed to play.

\section{The Relationships Between: Magda-Father-Servants}

The relationships that exist between Magda and her father and her father's servants reveal the mysterious personalities of the three protagonists. Magda is infatuated by her father who resorts to his mistress servant. Finally, Klein Anna loves Hendrik and gets married with him. All that Magda needs from her father is unreachable. Her father is insensitive to her request. She knocks on her father's door and says: Daddy, can you hear me...I can't sleep...I am feeling strange. What should I do? [1]. Despite her efforts, Magda's father wakes up furiously and bitterly. Magda is disappointed because she does not receive the support she expected.

Magda's father relationships with his servants are based on Master-servant or employer and employees bonds. The first relationship is between Magda's father and Hendrik. The latter comes from Armoede, in Kobus to find employment. The dialogue between the employer and his employee witnesses the will of Magda's father to recruit Hendrik:

Hendrik was not born here. He arrived from nowhere, the child of some father and some mother unknown to me, sent into the world in hard times, with or without a blessing to earn his bread. He arrived one afternoon asking for work..." Baas" good day, bay baas. I am looking for work" [1].

Hendrik's recruitment by Magda's father brings about social turbulences in the house. It destroys the harmonious atmosphere that existed between Magda and her father. Hendrik and Klein Anna are permitted to live in the house. Hence the beginning of Magda's father's sexual intercourse with his servant.

Hendrik's recruitment process: Listen carefully, Hendrik. Go to the kitchen and tell Anna to give you bread and coffee. Tell her she must fix a place for you to sleep. Tomorrow morning early I want you here. Then I will tell you your job. Go now (Coetzee, 1999:22). Klein Anna is a wife figure for Magda's father. She is a servant who comes from a remote place to settle in a white colonizer's family. But Klein Anna is not a complex black female servant. She is ready to 
assume her social status among Magda's family. She informs: I am not interested in becoming one of those people who look into mirrors and see nothing, or walk in the sun and cast no shadow [1].

Magda's father's relationship with Klein Anna becomes more and more serious. Magda is jealous of them. She knows that her father can ask Magda to take care of the servant and do all the household. Magda tells that in a couple of months, she will be bringing her father and her mistress breakfast in bed. She will have to wash out the mistress's soiled underwear [1]. Magda sees Anna as a rival and competitor. Sexually, Klein Anna is more attractive and more satisfactory. Magda admits I could never make him happy. I was never more than the dull dutiful daughter. I only bored him [1].

Gamal quotes Clingman who suggests that Magda is the "personification of alienation" par excellence. He puts: from the foreign land, the continent, and its peoples...is the reality of colonial enterprise [7].

Magda is alienated by the people who do not want to get married with her. This refusal and indifference make her an old woman, a spinster. She is alienated by the triangle schema. Firstly, she is alienated by the relationships between her father and his new bride, secondly by the sacred marriage between Hendrik and Kein Anna. Finally Magda is alienated by the relationships between her father and Klein Anna.

\section{Magda's Fulfillment of Feminine Self}

Any human being needs to fulfill his/her sexual desires. Satisfying one's sexual desires is a natural phenomenon. In In the Heart of the Country, Magda expresses her need to find a male partner. She is an old woman, a feminine creature. She needs to be seen as a true and authentic woman. She confesses:

I am incomplete. I am a being with a hole inside me. I signify something. I do not know what, I am dumb. I stare out through a sheet of glass into a darkness that is complete, that lives in itself, bats, bushes, predators and all, that does not regard me, that is blind, that does not signify that merely is. If I press harder the glass will break, blood will drip, the cricket-song will stop for a moment and then resume. I live inside a skin inside a house. There no act I know of that will liberate me into the world. There is no act I know of that will bring the world into me. I am a torrent of sound streaming into the universe $(\ldots)$ [1].

Magda's yarning for sex is noticed whenever she is alone. She imagines to be an "O" that refers to her vagina. She is unmarried and cannot explain the reasons for her loneliness and emptiness. She vouches: There is a hole between my legs that has never been filled leading to another hole never filled either. I am an "O", I am sometimes persuaded, and it must be because I am a woman [1]. The "O" that Magda talks about refers to "nothingness", to "Zero". It mostly connotes women's weakness and emptiness in a patriarchal society. It also alludes to femininity. Moreover, the "O" signifies her unbroken "egg" which content has never been discovered and tasted. She stages:

He tells her what I need. He tells her that I need a man that I need to be covered, to be turned to be a woman. I am a child, he tells her, despite my years, I am an old child, a sinister old child full of slate juices...someone should make a hole in me to let the old juices run out [1].

The "O" and the "juices" refer to femininity. Magda's wish is to experience sexuality and see the blood of her broken virginity. Gamal examines Sigmund Freud's supposition in "Lecture XIII: Femininity". He defends that female genitalia are the "atrophied" version of the males, and that the girl-child is always initially homosexual [5].

Magda's fantasy is not only confined in her father and Hendrik. She even fantasizes for Klein Anna. She imagines being inside her body. Therefore, many people blame the spinsters for staying without husbands. Finally, most of them become lesbians. The desire for sex is manifested when Magda imagines her body inside Klein Anna's:

I would like to climb into Klein Anna's body. I would like to climb down her throat while she sleeps and spread myself gently inside her, my hands in her hands, my feet in her feet, my skull in her benign quiet of her skull where images of soap and floor and milk revolve, the holes of my body sliding into place over the holes of hers, there to wait mindlessly for whatever enters them, the songs of birds, the smell of dung, the part of a man, not angry now but gentle [1].

The absence of mother figure in Magda's life causes loneliness, emptiness and alienation. To fight against alienation, Magda resorts to her male servant. She needs to be integrated by the society in which she lives.

\section{When the Male Servant "Humanizes" his Female Master}

Magda imagines her own world in which she feels alienated. In The Heart of the Country, Magda's father hires a black servant, Henrik. Coetzee also uses Hendrik to be a solution to Magda's eternal problem. The colonial system during Apartheid did not allow the Servants to live among their masters. They lived in remote places. They shuttled back and forth between where they lived and their workplaces.

However, the invitation of Hendrik and Klein Anna by Magda's father to come and live among them in the house is a particular case. Magda's father fulfills his sexual desires with Klein Anna. After her father, Magda and Hendrik have sexual intercourse. Magda complains that she is not considered as a woman. Since 
having sexual intercourse makes Magda a human being, Henrik "humanizes" Magda. Thus, she is a human being, an authentic woman:

He lies beside me on his back, snoring, asleep. My hands lovers his man's part, held there by his hand...I feel only a dampness and softness. I pull the green counterpane over myself: A I now a woman? Has this made me into a woman? So many tiny movements, acts, movements one after another, muscles pulling bones this way and that, and their upshot is that I can say, I am finally a woman, or Am I finally a woman? [1].

Magda is committed to finding a man to assert herself as a true woman. Her sexual intercourse with Hendrik is a satisfaction. Before her sexual intercourse Magda did not have neither a human identity nor a gender.

There are controversial analyses about Hendrik and Magda's sexual intercourse. While some consider the sexual intercourse as a rape act, others defend that the sexual intercourse is done with consensus. Indeed, Magda prepares the scenes in her mind. She does not express any refusal or anger during the act. Coetzee reveals: don't be afraid, everyone likes it, hold tight and it won't hurt [1]. In turn, Magda explains... He bends and fumbles for the bottom of my dress. I scuffle, but he finds it and his fingers come up between my legs. He slides down my body, dragging at the elastic of my pants, scratching me [1].

Most female masters use the alibi of rape to justify their "disgrace" after having sex with their servants. During Apartheid, having sex with one's servants was humiliation. In Disgrace, J. M. Coetzee depicts this "rape" between Lucy, Pr David's single daughter, and her grouping-gang rapists. Lucy pays back a debt that she has never been responsible for. Lucy is a young farmer who isolates herself from the town to live in the countryside. Finally, she is raped by unknown people. The rape act she never reports is a form of dishonor. Like Lucy, Magda's sexual intercourse with Hendrik is considered as a rape to flee disgrace and dishonor. Magda concludes: I am not a philosopher; Women are not philosophers, and I am a woman. A woman cannot make something out of nothing... it was necessary to fill me out, to give me life [1].

\section{Regrets, Humiliation and Passion}

"A woman cannot make something out of nothing" [1]. Some women are ready to do sacrifices to achieve their aims. Magda's deliberate sexual intercourse with her male servant engenders many consequences such as regrets, humiliation, frustrations, etc. Magda regrets: ... It would cost me nothing to go to the kitchen and fetch a knife and cut off the part of this man with which he has been offending me. Where will it all end? What is there left for me now? [1].
In Beyond the Horizon [8] Amma Darko displays this regret through her character Mara. She goes to Germany to gain a lot of money. Mara sends material things to her progeny in Ghana. But the money she sends is ill-gotten gain. She turns herself into a prostitute to satisfy her financial problems. She acknowledges having earned a lot of money but has lost her dignity and honor: "as for me, there is nothing dignify and decent left of me to give them [8].

Magda owns up.

I cannot honestly see why he leaves his wife's bed for mine...He turns me on my face and does it to me from behind like an animal. Everything dies in me when I have to raise my ugly rear to him. I am humiliated: Sometimes I think it is my humiliation he wants [1].

The loss of her values, her humiliation and disgrace are caused by her desperate desire to "love and be loved", to "need and be needed". Her frustration of not being seen as a woman renders her mad. She kills her father and has sexual intercourse with her servant. All these events and tragedies make her feel alone. The rest of her life is symbolized by loneliness and emptiness:

I am alone again, alone in the historical present: Hendrik is gone, Anna is gone with him, they fled in the night without a word, taking nothing that could be strapped on a bicycle...I huddle in the storeroom, the child of the stone floor seeps into my bones, the cockroaches stand around me waving their curious antennae, and I fear the very most [1].

\section{CONCLUSION}

In In the Heart of the Country J. M. Coetzee shifts from racial and discriminatory issues to a literature of imagination. In the novel Coetzee presents Magda, an unattractive old spinster who longs for an affirmation of feminine self through the people around her such as her father, klein Anna, Hendrik, etc. This article reveals the relationships between Magda and her dead mother and father. This parent/daughter bond is based on betrayal by her dead mother who does not succeed to give an heir son to her husband. It is also based on fantasy for her father whom she kills for using Klein Anna like a wife. The indifference of Magda's parents pushes her to resort to Henrik to fill the "hole" or the "O" to satisfy her sexual desires. Magda asserts herself as a true human being first and second as a woman. Therefore, resorting to Hendrik as a husbandfigure worsens her social situation. Instead of satisfaction, Magda becomes alone, humiliated, passionate and frustrated.

\section{REFERENCES}

1. Coetzee, J. M. (1999). In the Heart of the Country. London: Vintage.

2. Coetzee, J. M. (2013). Disgrace. Penguin Books.

3. Coetzee, J. M. (1974, 1982). Dusklands. Van Press, Secker\& Warburg. 
4. Atta, S. (2004). Everything Good Will Come. Interlink Book.

5. Gamal, A. University of Mysore. (2013). "She needs to be needed": Isolation and Desire in J. M. Coetzee's In the Heart of the Country. Appeared The Criterion-An International Journal in English. Issue 12, February 2013.

6. Kambarami, M. (2006). Femininity, Sexuality and Culture: Patriarchy and Female Subordination in Zimbabwe. South Africa: ARSRC.
7. Clingman, S. (1991). "Beyond the limit: The Social Relationships of Madness in Southern African Fiction". The Bounds of Race: Perspective on Hegemony and Resistance. Ed. Dominick La Capra. Lthacal and London: Ornell UP. 231-54.

8. Darko. A. (1991). Beyond the Horizon. Der Verkauft Heinemann. 